\title{
The Analysis of Poverty Variables in the Balkan Region- the Case of Kosovo
}

\author{
Prof.Ass.Dr. Hysni Terziu \\ Iliria College \\ hysni.terziu@hotmail.com
}

\section{Doi:10.5901/ajis.2015.v4n1s2p297}

\section{Abstract}

Poverty continues to remain a major challenge during the whole period of transition, since the collapse of communism and which is continuing even today. In this article, the macroeconomic trends in the Balkan region are treated in synthesized way, with a special emphasis on Kosovo for the years of transition. In addition, the paper is focused on some economic indicators that have direct or indirect impact on labour market policies and employment policies. The trend of these indicators is analyzed in terms of nominal and real convergence, aiming at the progress of the Kosovo economy during the years of transition in the process of integration into the current level where it is located, as well as the challenges that has faces in meeting other standards in political and economic system. The focus of this analysis are the employment policies as well as the structural reforms, institutional reforms of the labour market, policies for the reduction of the unemployment rates, generating of new work places, taking into account the fact that in Kosovo the unemployment especially at young people is very high. The purpose of this study is to identify the current state of poverty, considering that the state should take some measures to reduce its level by being based on market instruments of labour and employment policies, migration, remittances and their impact on the labour market, its structuring and their components in the Balkan region, but with particular focus on Kosovo. Poverty is a cycle that is repeated constantly and has negative impacts not only on the economy of a country but also on the lives of its citizens. Its causes are as complex as poverty itself. On the other hand, poverty reduction is as a result of economic growth. In the reduction of poverty, government plays a very important role. So, the government with its policies can cause an increase in the economic growth and then reduce the poverty level. The situation, instead of being relaxed, nowadays, it is experiencing difficult times. This is happing because the world today is undergoing through a global financial crisis which had started in the United States in 2008 and which has spread all around the globe. It can be said that this global financial crisis has been the longest that this world has recognized. For this reason, to the government of a country is added one more task, which is even more difficult, that through its policies to do the impossible in order to overcome this crisis and to send the respective country towards economic development, and thus to reduce poverty.

Keywords: Poverty, Global Crisis, Government Policies, Economic Development, International organizations, the World Bank, Donors

\section{Introduction}

Poverty is a phenomenon that cannot be easily determined. It is more a multidimensional concept and that its definition and measurement requires hard work and many data. A more intuitive concept is the concept of absolute poverty, which usually refers to an absolute idea of deprivation of the basic requirements for survival. Another concept of poverty is that of relative poverty, according to which, the poor are considered those who lack a certain amount of income derived from the average or medial of income in a given society. Relative poverty and income inequality shows how various divisions of social levels are made.

Poverty, as a multidimensional and complex phenomenon, is not related only to income or consumption (considered as monetary dimension of poverty) but also to non-monetary dimensions such as education, health, gender equality, water supply etc. These dimensions are also included in the Millennium Development Goals- MDGs.

However, there is not a perfect measure of poverty, different measurements of poverty are complementary and its choice will depends on the reason for what it will be used. National measurements of a country cannot be used for comparisons among countries because of differences in the design of surveys. To enable these comparisons, there should be calculated the international poverty line (World Bank gives the calculations of the poverty lines as 1.2 and 4 dollars per day) which shows how to achieve the same standard of living in any country.

In this paper, we deal with some monetary measures of poverty indicators as well as with some non-monetary measures. In the second part, a special attention will be on the description of these poverty indicators in some countries of the Western Balkans. In the third part, will be provides special analyses for the case of Kosovo.

Since the end of the armed conflict in 1999, the progress on the improvement of living standards in the Republic of 
Kosovo, including the solid macroeconomic performance, has been slow and unequal. Immediately after-war period, Kosovo experienced rapid economic growth and the GDP grew at three digit numbers, which was greatly affected by the donors as reconstruction efforts. In addition, Kosovo was also able to face the global financial crisis of 2008-2009 better than most other countries in the South East Europe (SEE). In fact, Kosovo and Albania were the only countries in SEE that in 2009 recorded positive growth of GDP.

Sociologists, when they talk about poverty, think that they should debate just within the way of living. However, today, poverty is divided into: relative poverty and absolute poverty.

Relative poverty indicates that a person or a group of persons are poor in comparison with others, or in comparison with what is considered to be a fair standard of living, or the level of consumption in a given society.

While absolute poverty suggest that people are poor in comparison with what is considered to be the standard of minimum requirements. E.g. while in the developed countries a poor person is relatively poor in our country then the same person can be regarded as poor in absolute terms. This means that poverty, namely its types, differ from country to country. However, both types are present.

\section{Monitoring Indicators of Poverty}

Poverty monitoring indicators are divided into two groups: monetary indicators and non-monetary indicators of poverty.

\subsection{Monetary indicators of poverty measurement}

Monetary indicators measure the poverty level in monetary terms by either using the level of consumption, incomes or expenses. Many analysts argue that if the consumption information is obtained by monitoring the households, which is very detailed, then it may be a better indicator of poverty measurement than if it will be measured by using the level of incomes ${ }^{1}$. Monetary indicators of poverty measurement are widely recognized and belong to the family of indicators developed by Foster, Greer and Thornecke which are recognized as FGT indicators (Foster, Greer and Thorbecke, 1984). They are described as follows:

- Head-count index or percentage of poverty is calculated as the ratio of the number of persons who are below the poverty line to the total number of population. It is an indication that is simple to compute but that presents two problems: firstfully, a reduction of the level of income of the poor people does not show us how much poor are the poor, and secondly, this indicator does not describe the distribution of income among the poor.

- The poverty gap index, measures how far the income or consumption of an individual is from the poverty line. It is a measure that shows how "bad" is the poor. This indicator is better than the percentage of poverty. But, even this indicator has its disadvantages; it is unaware of the number of individuals below the poverty line and by the way on how the income is transferred among the poor.

- Poverty severity index, called differently also as Foste-Greer-Thorbecke Fost index, measures the severity of poverty by putting it in power of square and averaged income gap between the oppressed and the poverty line. This indicator is of particular importance because it takes into account inequality among the poor.

- All these three indicators are reported from the national statistical agencies and are used by the state authorities as tools to monitor changes of poverty over time.

\subsection{Non-monetary indicators of poverty}

On the other hand, non-monetary indicators of poverty (or indicators of basic needs) are based on the idea that poverty is associated with the deprivation of certain basic needs such as education, health, food-nutrition, supply with water etc.

Some of these indicators, as most widely used, are2:

- Education Indicator: in terms of this indicator can be mentioned the rate of illiteracy among adults, the rate of enrolment, the average years of schooling, etc.

- Health Indicator: are included indicators such as life expectancy at birth, infant mortality rate, the percentage

${ }^{1}$ Ravallion, M., (1998), "Poverty Lines in Theory and Practice", Washington, D.C.: The World Bank

2 Coudouel, A., Hentchel, J.S. and Wodon, Q.T., (2004), "Poverty measurement and analysis", Washington, D.C.: The World Bank, pg. 29-35. 
of women who receive health care, etc.

- Indicators of Food-Nutrition: such as underweight indicator which can be measured by anthropometric measurement of weight per age, height per age and weight per height etc.

- Water supply, sanitation and public services: such as the percentage of households that have water supply, regular supply of electricity, heating, etc.

\section{The Level of Poverty in some Balkan Countries}

As mentioned above, poverty can be measured at global, national or local level. There is not a perfect measure of poverty; various measures are complementary to each other.

In addition, poverty is not only a problem of developing countries but it is present also in developed countries. In developing countries, poverty highly widespread and is characterized with hunger, lack of living resources, unemployment, illiteracy, epidemics, lack of medical services and water shortages. However, in developed countries, poverty is characterized by social exclusion, rising of unemployment and low wages. In the table below, are provided the data on monetary indicators of poverty for some countries of the Balkan region.

Table 1: The level of poverty in some Balkan countries

$\begin{array}{lcccc}\text { Country } & \text { Year } & \text { Percentage } & \text { Deepness } & \text { Severity } \\ \text { Albania } & 2005 & 18.5 & 4.0 & 1.3 \\ \text { Bosnia and Herzegovina } & 2001 & 19.5 & 4.6 & 1.6 \\ \text { Bulgaria } & 2001 & 12.8 & 4.2 & 1.9 \\ \text { Croatia } & 2004 & 11.1 & 2.6 & 1.0 \\ \text { FRY Macedonia } & 2003 & 21.7 & 6.7 & 2.8 \\ \text { Rumania } & 2006 & 13.8 & 3.2 & 1.1\end{array}$

Source: World Bank (Poverty Assessments)

BOSNIA AND HERZEGOVINA - Bosnia and Herzegovina is one of the states of the Former Republic of Yugoslavia, which gained independence in 1992. Then very soon, in 1995, it was engulfed by the civil war which among other things led to the reduction of revenues. The measurement of poverty level is based on the use of consumption as an indicator of welfare. The data obtained from the World Bank in 2001, regarding the level of poverty in the Republic of BosniaHerzegovina, showed a percentage (headcount index) of 19.5, which means that 19.5 percent of the population live below the poverty line. In addition, the World Bank study (2003) included a detailed analysis of the spatial dimensions of poverty in Bosnia and Herzegovina (World Bank, 2003) ${ }^{3}$.

Poverty mainly refers to household heads with three or more children. This group of households head represents a large proportion of the poor (which is 69 percent of the total). Another social group, which represents a high degree of poverty, is the group of refugees and of displaced (34 percent of this group are below the poverty line). Most of the poor did have neither the second nor the third-level of education (90 percent of total). The same analysis has shown that most poor families with children were families who were depended on one person who has incomes for living (56 percent). Spatial analysis of poverty monitoring has shown that rural or semi-rural areas have suffered from higher rates of poverty (20 percent to 24 percent for rural and semi-rural areas, respectively) compared to urban areas (14 percent). The civil war in Bosnia touched many rural communities, who were forced to migrate within a state towards semi-urban or urban zones. As a result, the figures of urban areas include also the refugees from rural areas of Bosnia.

The overall conclusion was that local economic conditions played an important role in the determining of poverty level of families, however, this analysis does not include any information at the community level, making it impossible to clarify the reason why certain areas show high levels of poverty.

In addition, poverty represents a threat to a large proportion of the population in the European Union, according to Eurostat data. In Bulgaria, 42 percent of Bulgarians face this danger, and then follow Romania with 41 percent, Latvia (38 percent), Lithuania (33 percent) and Hungary (30 percent). Less affected by poverty are the Czech Republic (14 percent), Sweden and the Netherlands (15 percent), Austria, Finland and Luxembourg (from 17 percent).

3 The World Bank, (2003), "Bosnia and Herzegovina: Poverty Assessment", Washington, D.C.: The World Bank 
In 2010, 115 million people or 23.4 percent of the population in the 27 member states of the EU, face the risk of poverty and social exclusion. This means that they are exposed to at least one of the future risks: the risk of poverty with incomes smaller from 60 percent of the national average income receipt of social assistance, serious deprivations material (failure of account payment, clothing, heat, consuming protein) and poor work potential of adult members in the household (under 20 percent of the overall potential of the previous year).

BULGARIA - In Bulgaria we have the period 1995-2001, which was characterized with three integrated studies of Bulgarian families. From the last study were taken the below data which belong to the year 2001. In order to measure the level of welfare (and poverty) in Bulgaria, was used the level of consumption, as the basis to measure the level of poverty.

According to this indicator, the poverty in 2001 was 12.8 percent (World Bank, 2002). Bulgaria had a profile of classes which were hit by poverty, which characteristic resembles also other European countries that have recently or are in the process of entering the EU. Big families, living in rural areas and which have small children and low education, and also the ethnic groups such as Roma, have increased probability of becoming part of the poor class.

Large families which are about 30 percent of the population, account as 60 percent of the poverty. The percentage of the poor in rural areas (23.7 percent) is almost four times higher than in urban areas (5.9 percent). Research results show that there is a strong link between poverty and education (individuals who have low levels of education are only 36 percent of the population, are of 18 years old and higher, but they account for approximately 80 percent of the poor $)^{4}$. The main problem for the Bulgarian economy during the transition period was the non good performance of the labour market which was characterized by high levels of unemployment and also of the poverty.

CROATIA -The development process of Croatia was significantly impacted from its separation from the Yugoslavia and also from the civil war which happened in the after month. Recent research, by using different methods for measuring the standard of living, ranked Croatia in an better position compared to other new countries of the EU (Matkovic 2007).

This does not mean that the Croatian economy does not have any problem to worry about. Inefficient government policies, especially slow fiscal policy, led to the decrease of the level of competition and increased the unemployment level, which in turn impacted the levels of inequality. This proved to be a major problem for the Croatian economy.

According to World Bank's estimates, the level of poverty in Croatia is relatively low (World Bank 2007). Approximately, 11 percent of the population is poor while a further 10 percent of population is at risk of being poor in the sense that their average consumption is less than 25 percent of the poverty line. According to the estimates made by the World Bank, based on the observation of the household budget, most of the poor (3/4) lived in households where the head had only primary education or even less, because these people either had jobs with very low pay or had no job at all. A significant proportion of the poor (40 percent) lived in a household where the head of the household was retired. Statistics suggest that the unemployed poor accounted for a small percentage of the total poverty, but this is a passive working age.

A portion of the poor in Croatia are classified as "new poor", a sub-class which was created during the transition period. This group includes small farmers, retirees, and those who are employed in the processing agriculture industry ${ }^{5}$. If we speak with spatial terms, rural region and central rural region of Croatia appear to have higher rates of poverty (almost twice the average risk of poverty).

FORMER YUGOSLAV REPUBLIC OF MACEDONIA - The information presented for this country of the Balkans belong to the Living Standards Study developed in 2002-2003. According to the calculations made, 21.7 percent of the population live below the poverty line but are characterized with a uniform distribution across the regions of the country (World Bank, 2005).

The percentage of poverty is higher in rural areas rather than in urban areas, with growing trends around Skopje. The poverty rate is also higher in large families and in those families with many young children, specifically more in those families which have a total number of members of four (which is the model number of members in a household in Macedonia) poverty rate increased more. Said in other words, 34 percent of all households that have six or more members live in poverty. Having a large number of children, who are too young to provide assistance in growing the revenues of the family, has a direct impact on poverty. It cannot be said that there are large differences in the proportion of the poor based on the gender of the household head (in 2003, 21 percent of male-headed population were poor, compared with 17 percent female headed). There is a negative relationship between level of education and poverty.

\footnotetext{
${ }^{4}$ The World Bank, (2001), "Bulgaria:: Poverty Assessment", Washington, D.C.: The World Bank

5 The World Bank, (2007), "Croatia - Living Standard Assessment: Volume I \& II", Washington, D.C.: The World Bank 
Looking from the prospect of poverty correlated with indicators like education, unemployment (23 percent of the unemployed are poor), employment by data indicated that in Macedonia there is a strong correlation between them and the poverty line ${ }^{6}$.

ROMANIA - For Romania, the World Bank has recently developed two major studies on poverty. The first study was published in 2003 and the second study in November 2007 (World Bank 2003 and 2007 respectively). It can be easily suggested that in Romania there is a clear link between the economic growth and the reduction of poverty, the improvement of the economy after 2000 brought poverty reduction figures. One of the most important determinants of poverty in Romania, as elsewhere, is the level of education. In Romania, the poor rate among adults with high school is very low (0.7 percent in 2006); however, the lower level of education then there is higher the degree of poverty. A related issue was that the poverty rate also depends on the status of the work. The risk of being poor was much higher among the self-employed farmers (32 percent) and the unemployed individuals (27 percent) in 2006. Is noted a considerable regional differences in terms of poverty by working status ${ }^{7}$.

In terms of poverty in Romania, there are significant regional differences. For example, in 2006 (the latest data), is suggested that the poverty rate in urban areas was 6.8 percent, while the respective figures for rural areas was 22.3 percent. The regional analysis reflects in large measure this fact; regions with large urban centres generally have lower rates of poverty. Thus, the Bucharest region presents the lowest percentage of poverty (4.5 percent). The highest poverty can be found in the North-Eastern region (20.1 percent) and in South-West region with 19 percent. Larger households (five or more) had a greater probability (three times higher) of being poor compared to small ones. The young people were in greater risk compared with other age groups to be poor. As in some other Balkan countries, the risk of being poor is much higher for Roma. In the case of Romania, the percentage of the poor is much higher for Roma people. In the case of Romania, the percentage of poor Rome was four times higher than the national average in 2006.

Due to the global economic crisis, the poverty rate in Romania, this year, will rise to 7.4 percent from 5.7 percent as it was last year. In one report published by the World Bank, was suggested that the poverty rate in the Balkan country includes the number of people living on less than three dollars a day8.

It is anticipated that this year, the number of Romanians who will live in poverty threshold will be increased from 1.22 million from what it was last year to 1.6 million this year. The numbers of children, who will suffer because of poverty, will grow for almost for 3 percent, from 250,000 as it was last year to 350,000 this year. In recent years, due to economic growth, the number of poor in Romania was significantly reduced from 2.1 million in 2007 to 1.2 million last year. Poverty mostly hits the children and farmers, who together make up around 55 percent of the entire population, which has been hit by poverty.

The World Bank has criticized the Romanian system for social protection, because it spends the least per capita for social protection among European Union member states 9 .

In the EU, 27 per cent of children under 18 years old in 2010 had been exposed to the risk of poverty or social exclusion, versus 23 percent of the population of working ( age from 18 to 64) and 20 percent of the elderly (over 65 years). Children are mostly hit in all the 20 member countries, where the greater percentage exists in Romania (48.7 percent) and Bulgaria (44.6 percent), while in Finland is 14.2 percent, in Sweden 14.5 percent. Greater risk of poverty for the elderly is in Bulgaria (55.9 percent) and Romania (38.9 percent).

ALBANIA - As the previous government, during the period was talking for a financial stability, the opening of new jobs, figures which already confirm the contrary. The increase of the public debt beyond any limit, increase of financial gap, unrealization of the income, lack of credit to the economy, can all inevitably lead to a painful factor- that of rising poverty. If the yesterday's government never accepted this fact, figures already confirm this, even though they come from a statistical institution that has little confidence in the accuracy of the figures. But without going beyond this perception, the figures which were released yesterday from the Institute of Statistics (INSTAT) show an increase in poverty in the past five years. According to the Living Standards Survey, for the year 2012 the level of poverty in Albania had reached 14.3 percent, while in the end of 2008 it was 12.4 percent. INSTAT makes it known that there are more than 400

\footnotetext{
${ }^{6}$ The World Bank, (2005), "Macedonia, former Yugoslav Republic of - Poverty Assessment for 2002-2003", Washington, D.C.: The World Bank

7 The World Bank, (2003), "Romania - Poverty Assessment", Washington, D.C.: The World Bank

8 The World Bank, (2007), "Romania - Poverty Assessment, Analytical and Advisory Assistance Program", Washington, D.C.: The World Bank

${ }_{9}^{9}$ KosovaPress, 2009, Rritet numri i te varferve ne Rumani, http://www.kosovapress.com/sq/arkiva/rritet-numri-i-te-varferve-ne-rumani78330/?old=1 [02.02.2015] 
thousand Albanians who live on less than 4,900 leks per month. In growth, have resulted also the extreme poverty or inability to meet basic nutritional needs. According to INSTAT this data reached 2.2 percent, from 1.2 percent as it was in 2008. The city with the highest rate of poverty is Kukes with 21.8 percent, while with lowest rate of poverty is Vlora with 11.7 percent. In addition, except the increase of poverty, what stands out more is its shift from rural to urban areas, a phenomenon that, according to INSTAT, can be explained by internal displacement of the population ${ }^{10}$.

Poverty, according to the figures for the part of the population where the real monthly consumption per capita is under 35 euro (2002 prices), has increased from 12.4 percent in 2008 to 14.3 percent in 2012. In previous years, poverty has declined from 25.4 percent in 2002 to 18.5 percent in 2005 and 12.4 percent in 2008. This means that about 28,896 individuals, in addition to 373.137 poor individuals in 2008 , have fallen into poverty. Extremely poor population, defined as individuals who have difficulties at meeting the basic food needs, has increased from 1.2 percent in 2008 to 2.2 percent in 2012. Extreme poverty fell from 4.7 percent in 2002 to 3.5 percent in 2005 to 1.2 percent in 2008. In 2012, poverty has increased in both urban areas (2.2 percent) and in rural areas (2.3 percent). Other indicators of poverty have also experienced growth since 2008.

Two other alternative indicators, except the poverty level (percentage of poor), are the poverty gap and severity of poverty.

The poverty gap has increased from 2.3 percent in 2008 to 2.9 percent in 2012. The increase of poverty has been associated with increase of the regional poverty. Unlike the year 2008 when the mountain areas were the only ones with a slight increase of poverty, the year 2012 has been specifically the mountainous areas that have recorded the reduction in poverty figures. In these areas, poverty has declined from 26.6 percent in 2008 to 15.3 percent in 2012. However, this decline may be also due to the movement of population, which is still continuing nowadays, from the mountainous areas to other regions. Consequently, the hosting regions may share the burden of these movements, which may be among the reasons that bring a general increase in poverty. For example, in coastal -seaside areas, which have the greatest increase in poverty, 17.6 percent of the population is poor compared to 13 percent in 2008 . Tirana has experienced a significant increase of poverty. Compared to 2008, the percentage of the population considered poor has increased from 8.7 percent in 2008 to 12.6 percent in 2012. These are the arguments of INSTAT for the increased poverty in certain areas, but there is a common denominator which is that the level of poverty is increasing at very frightening degree, which requires a deep reflection on future economic and social policies in order to generate new jobs and to mitigate these indicators ${ }^{11}$.

Poverty in Albania is measured through monetary indicators of consumption, given the fact that Albania is a country characterized more as an agricultural economy and with a high degree of informality (INSAT, World Bank, 2006). We may be acquainted with the characteristics of the poor by examining the frequency of poverty, by looking at geographic or demographic concentration as well as education profile of the poor. Knowledge of the characteristics of the poor is important because they inform and assist policy makers to design various programs to help people in need. Poverty in Albania has inverse relation with the degree of education. Families with many children and elderly are closer to the poverty line. Families, where key family head is young and uneducated, are more vulnerable to poverty. Contrary, when the households have heads is in emigration, are not characterized by a high risk of falling into poverty.

\section{Monitoring Indicators in Kosovo}

The problem of poverty is one of the biggest problems which today are presented in all around the world. We are witnessing the fact that besides many developments that are taking place in the world today, especially in socio-economic terms, Kosovo is not excluded from this part of the world. The recession crisis, the problems with unemployment, poverty, numerous protests, the creation of new movements as a result of dissatisfaction among others, are some of the problems that are being faced by the contemporary society today, despite the fact that this society is regarded as a society which has been living with the higher level of luxury that the history can ever remembers.

However, this trend of problems is also following the state of Kosovo. In the long mileage of challenges and problems that Kosovo has been facing, is included also the phenomenon of poverty. Early sociologists have tried to give prognosis on this phenomenon and as such measure the poverty with the concept of necessary resources/tools for

10 The World Bank (2012), "Evropa Juglindore: Raporti i Zhvillimeve Ekonomike Nr.3 - Nga recesioni i dyfishtë në reforma të përshpejtuara", pp.45.

11 The World Bank and INSTAT, 2013, "Albania: The Trend of Poverty 2002-2005-2008-2012" 
existence. From this, is implied, that poverty in logical sense can be understood as a status or condition of people who lack basic resources/tools for living.

This elaboration can be one of the many definitions of poverty and that presents a cancer for society, especially for the Kosovar society, considering the fact that every year to the Kosovo are added almost over 35 thousand young people who are able to work. As such, about 60 percent of Kosovo society structure consists mainly from the young people aged 15-35 years.

Since the period after the war and until to date, although there has been continuous decrease and increase of poverty, the term poverty has been a term that has preoccupied our society. According to the World Bank Report "Southeast Europe- Economic Development Report" the unemployment rate in Kosovo is around 45.4 percent. While, according to $\mathrm{KSA}^{12}$, the unemployment rate is 35.1 percent, in urban areas is 28.5 percent and in rural areas is 40.1 percent. In addition, for males is 32.0 percent, for females is 44.4 percent and for the young people (age 15-24) is 60.2 percent. In addition, from a survey conducted by WB \& KSA \& UKaid regarding the workforce is noted that: "Only 23.9 percent are employed". But, according to reports of UNDP, Kosovo has over 43 percent of the unemployed; 34 percent live poverty with less than 1.42 Euros per day, and about 18 percent in extreme poverty with less than 94 cents per day "13.

According to World Bank data, around 200 thousand citizens of Kosovo live in extreme poverty, with only 1.20 euro per day. The statistics published from the Statistics Agency inform that around 30 percent of Kosovo's population, or more than 600 thousand Kosovars, spend the day with only 1.70 Euros. In 2011, the highest level of poverty is found among the unemployed, retirees and people with disabilities.

Referring to the composition of the poor population, it can be seen that nearly 30 percent of poor adults are unemployed. Over the two years, the poverty rate has been reduced for people whose main activity is the work with pay for 11 percentage points. The highest increase of poverty is observed among self-employed persons (6 percentage points) and among unpaid family workers (3 percentage points).

Despite the fact that the statistics every time changed, there is a decrease or increase in the data provided, the term poverty and unemployment exists in everyday vocabulary and is part of our society in Kosovo that apparently to not find the door to leave or at least to mitigate this phenomenon. This situation also reflects the fact that Kosovo is the poorest country not only in the region but also in Europe. To this statement, best answers the fact of the data provided from MMPs that "the number of registered unemployed in social work offices is around 272 thousand", even though in reality this figure could be even higher.

However, the increase was modest, subdued by a worsening climate for investment, decrease of foreign direct investment, weak governance and weak rule of law, and increased criminal behaviour (World Bank 2010). Remittances, that comes from the people who live abroad, have also declined during the start of the crisis. Therefore, Kosovo remains the poorest country in South Eastern Europe (SEE). In 2009, the GDP per capita of $€ 1.760$ (World Bank 2010) is the lowest in SEE, and as such places Kosovo as one of the poorest countries in Europe. Improving the employment figures is key towards the reduction of the poverty and increase of the living standards through faster growth and more inclusive ${ }^{14}$.

This report is focused on absolute poverty by comparing the living standards against a poverty threshold, which is held stable in real conditions in time and space. Poverty threshold is updated over time in order to be corrected for changes in prices. In this report, consumption has been used as a measure of welfare or individual property. Household consumption is calculated as the total value of household's spending on groceries and non-food items such those provided in the Survey of Household Budget Surveys (HBS). This survey is a national representative survey which is conducted on yearly bases and included evaluation of any food produced at home and consumed by the household. By adhering to the past practices in Kosovo, spending on long-term items and on leases are excluded from the consumption. The HBS surveys of 2009, 2010 and 2011 are based on a new framework sample of 2008, thus, the data are comparable for the three years. The living standards regarding the current value of a household consumption depends on the size of the family and also on the demographic structure of the household ${ }^{15}$.

\footnotetext{
12 Kosovo Statistical Agency

13 The World Bank and Kosovo Statistical Agency, (2012), "Report on Economic Development", Prishtina.

14 The World Bank and Kosovo Statistical Agency, (2011), "Poverty on consumption in the Republic of Kosovo for 2009", Prishtina: Office of World Bank in Kosovo.

15 The World Bank and Kosovo Statistical Agency, (2013), "Poverty on consumption in the Republic of Kosovo for 2011, Prishtina: Office of World Bank in Kosovo.
} 
For this reason, the household consumption is divided by the number of adult equivalents in the family to calculate the welfare indicator, which is equivalent consumption for the adults

Figure 1: Poverty and extreme poverty by residence (\%) 2009-2011
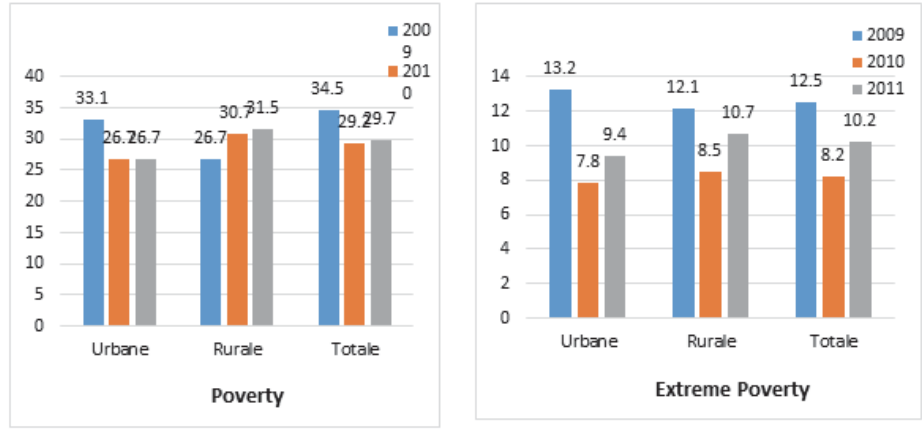

Source: HSB 2009-2011

In this report, have been used two boundaries of poverty, a poverty line that is considered adequate to meet the basic needs and a lower line for extreme poverty. After adjustments/ corrections for inflation, poverty lines and extreme poverty are:

- $\quad 2011: € 1.72$ and $€ 1.20$ per adult equivalent per day

- $\quad 2010$ : $€ 1.61$ and $€ 1.07$ per adult equivalent per day

- 2009: $€ 1.55$ and $€ 1.02$ per adult equivalent per day

The Poverty rate per capita measures the percentage of the population where the consumption of equivalent for adults is lower than the set poverty threshold. Based on HBS 2011 is estimated that 29.7 percent of Kosovo's population live below the poverty line while 10.2 percent of the population live below the extreme poverty line ${ }^{16}$ (Figure 1).

Comparing the data for the three years, it can be seen that the poverty rate is reduced by 5 percentage points from 2009 to 2010 and has increased marginally from 2010 to 2011 for 0.5 percentage points. The increased poverty in 2011 is within the margin of error in the sample of the HBS, which means that basically the poverty has not changed from 2010 to 2011. Poverty rates in three years are higher in rural areas except for the data for the extreme poverty of 2009 which suggest that is higher in urban areas (Figure 1).

Figure 2: Poverty gap index for poverty bourdon and extreme poverty 2009-2011

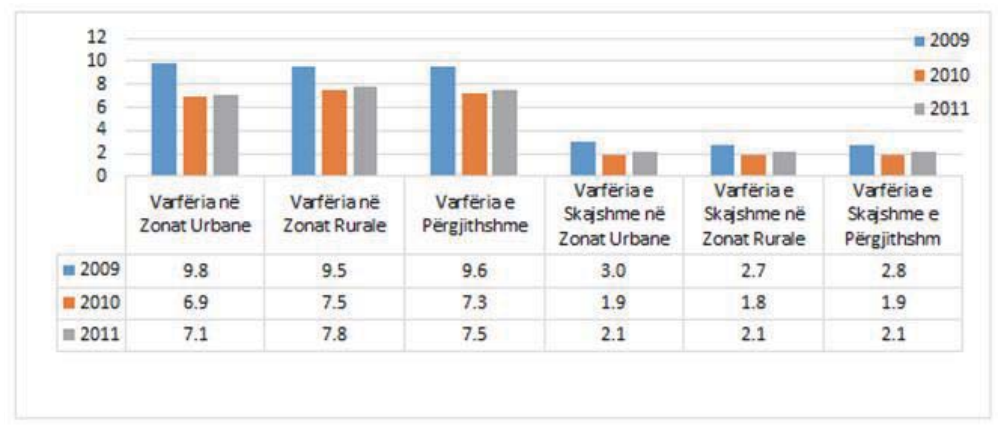

Source: HSB 2009-2011

16 The World Bank and Kosovo Statistical Agency, (2011), "Poverty on consumption in the Republic of Kosovo for 2009", Prishtina: Office of World Bank in Kosovo. 
The poverty gap measures the depth of poverty and takes into account also the percentage of the population that lives below the poverty line but also the size of the difference between the poverty line and the average consumer to the people found below the poverty line. Compared to the level of poverty, the advantage of the poverty gap is that computes/ identifies the changes in welfare that takes place below the poverty line, as is the case when households become less poor but not enough poor to cross the poverty line. From 2009 to 2010, the depth of poverty based on overall poverty has decreased while it has significantly increased from 2010 to 2011 17.

Similar trend has characterized the changes in the depth of extreme poverty. The depth of poverty is higher in rural areas in 2010 and 2011 while the opposite occurred in 2009. The depth of extreme poverty is almost the same in urban and rural areas.

Kosovo is ranked as ninth among the 25 poorest countries in the world, while it is in the first place (as the poorest country) in Europe. Regarding the world ranking, Afghanistan remains much wealthier and with more employed people compared to our country. The list is leaded by Zimbabwe, as the poorest and with most unemployed people in the world. While Kosovo ranked as the ninth has the index of poverty of 50.6 and the unemployment rate of 45.3 percent.

For the poorest country in Europe, the report suggests that the average annual income per capita is $\$ 7,400$. The report that was published from the Business Insider, includes 197 countries from Afghanistan to Zimbabwe and provides information for the Poverty Index for 2013. The report suggests that remittances in Kosovo come mainly from Switzerland, Germany and the Nordic countries and they are estimated to be about 18 percent of GDP. "Even though Kosovo's economy had an important process in the transition to a market-based system, unemployment continues to remain a major problem," as reported by the Business Insider.

After the Zimbabwe, the following countries in the list of the poorest countries in the world is Liberia in the second place, Burkina Faso as the third place and then continuing with Belarus, Turkmenistan, Djibouti, Namibia, Nepal while Kosovo is ranked in the ninth place. In better condition than Kosovo, in terms of less unemployment for 20 percent, then in the tenth place in the list is Syria, after it comes Sudan, then Lesotho, Kenya, Senegal, Marshall Islands, Afghanistan, Swaziland, Haiti, Yemen, Bosnia and Herzegovina, Gaza Strip, Maldives, Iran, Mauritania and Mali is ranked in the 25th place which was widely mentioned recently for recognition of Kosovo ${ }^{18}$.

Recent information that was present recently regarding the new wave of Kosovars that have migrated to the other countries, namely in Hungary with opportunities to deport in the other countries, undoubfully this is a sign of alarm that the Kosovar society has problems and challenges. These problems and challenges are exacerbated even more especially with the various statements that Kosovo has a job ... but, cannot be worked or there is no work?! We do not want to deal with such statements, but we want to deal with the substance of the statement in order to analyze the situation.

The need for a better life preoccupies the Kosovar society and every citizen and this best associates us with the poem of our great author Migjen, according to whom "misery is morsel which is not digested". Therefore, emigration is seen as a key competent to alleviate the poverty level and the unemployment rates, as well as creating better socioeconomic conditions. Broadly speaking, in Kosovo there is no work and if there would be work, with no doubt people would work. However, the work is missing and the only solution from the youth of Kosovo is seen the emigration as a search for better life (although it is known these states have their own problems).

Anyway, if we go back to the topic in question, where the Kosovars wave of immigrants who went in Hungary mostly and who were banned by the authorities, some of the emigrants also stated that they were mistreated by the Hungarian state shows clearly the problems of Kosovo society - especially with poverty. All these problems must certainly wake from sleep the Kosovo institutions, in order to undertake mechanisms to alleviate the situation of poverty and the problem of unemployment in Kosovo. On the contrary, Kosovo institutions will face various problems, especially in the visas liberalization process, but in the same time also to create a better image of the state.

Regarding the consequences of poverty, they can be numerous such as deep psychological pessimism, anxiety, depression. The side effects can also be severe such as suicide, which according to data from the war and until nowadays in Kosovo have occurred about 768 suicides, some of them undoubtedly are also associated with problems of poverty. Then, the consequences may be reflected in the crisis of values, morality, problems with the process of identity,

17 The World Bank and Kosovo Statistical Agency, (2013), "Poverty on consumption in the Republic of Kosovo for 2011, Prishtina: Office of World Bank in Kosovo.

${ }^{18}$ Business Insider, (2013), "The 25 most miserable places in the world", http://www.businessinsider.com/most-miserable-countries-inthe-world-2013-2?op=1 [23.01.2015] 
the frequency of domestic violence. The consequences can push people toward theft, various crimes, prostitution, and many actions of negative phenomena.

In conclusion we can say that poverty in Kosovo is not a product of the poor, but is the product of the political elite that apparently did not find the solution to this problem which cannot be prevented. If the adequate measures and mechanisms are not taken then we may easily come to the above mentioned problems.

Therefore, Kosovo institutions, together with the international partners, would need to: establish employment policies and economic development; local governments should provide support for foreign investors in order to have investments; especially to be done the proper management of public property. Then, to be created vocational training programs that will generate new work places and not for the people to complete the training and then to roam the streets.

Another element is also the forms of a program, as is the case with developed countries, in which citizens collect bottles and other things and send these wastes to the recycling companies in order to profit. Furthermore, this program may also have other positive effects, especially in the preservation of the environment and its management, as well as many other elements that can impact on concrete recommendations.

Thus, in this paper ware presented the data for the level of poverty in some countries of the Balkan region. The description was made in terms of monetary and non-monetary poverty measures. The level of poverty is measured using the consumer monetary indicator. According to these non-monetary indicators, in all these countries existed almost a same correlation with other indicators such as education, unemployment, number of members in a family, ethnic groups (Romania, Bulgaria), etc. To measure the poverty in Kosovo, is defined a level of real consumption which is regarded as the "poverty line", under which persons are considered as poor. In this brief description of poverty in Kosovo, is shown that poverty has increased significantly both in urban and rural areas. Poverty is in the inverse correlation with the level of education. Families, where the key holders are young and uneducated, the unemployed are more vulnerable to poverty, while households whose head is in emigration, are not characterized with high risk of falling into poverty. All these changes are explained with the role played by economic growth, migration, organization of rural production as well as programs for economic and social support

\section{Conclusion}

Poverty is a complex phenomenon that is related not only to income or consumption, considered as monetary dimension of poverty, but is also related to non-monetary dimensions such as education, health, gender equality, water supply etc. Poverty can be measured at the global, national or local level. There is no a perfect measure of poverty, various measures are complementary, whose solutions depends on what it will be used. This study presents a brief description of some important indicators of monetary and non-monetary measure of poverty in Kosovo, Albania and some other Balkan countries.

In 2009, approximately more than a third of the population (34 percent) lived below the absolute poverty line of $€$ 1.55 for an adult in daily equivalent while 12 percent lived below the extreme poverty line of $1.02 €$. The poverty gap index was 9.6, indicating that on average a person in Kosovo realizes only 72 percent of the poverty line. The poverty lines in rural and urban areas are almost equal but vary widely across seven regions of Kosovo. In the latest reports of the World Bank regarding the poverty assessment, the level of absolute poverty in consumption is significantly lower than reported by HSB 2005-06. Although the two surveys cannot be compared reliably, it is likely that at least some of the apparent poverty reductions are real when calculating the modest increase in GDP per capita and the observation that the inequality during this period has remained relatively low and unchanged.

Kosovo has a young population who is disproportionately poor so that over 40 percent of young people are under age 20 while 60 percent of the poor are younger than 30 years (compared to 38 and 56 percent of the total population under these ages). There is a strong link between education and poverty while for those who have completed the secondary and high school is much less likely to be poor compared to those who have not completed this education. Poverty rate per capita in 2009 was 38 percent among those who had only finished the primary school, compared with 28 percent of those who had completed the secondary school and 11 percent of those with higher education.

But only education is not enough. There is a need for more and better works. Almost half of the workforce in Kosovo is unemployed, and the unemployment is strongly linked with the poverty. The unemployed people in Kosovo are disproportionately young and female with the better level of education compared to the general population but not as good as those who have regular employment. The creation of good work places in order to reduce unemployment - not only for the current group of young people that can work, but also for the general population which is still in school - is the primary challenge towards the reduction of poverty in Kosovo. 


\section{Recommendations}

Considering the experience of recent shocks and the global crisis, below are some specific recommendations for the countries in order to better be prepared for the crisis.

Two entities in Bosnia and Herzegovina should continue their efforts to improve the targeting of their safety nets and to make the administration of social assistance more efficient and more transparent. Regular monitoring of social impacts is prevented by the lack of annual data on poverty and its distribution.

Macedonia, which had a pro-active status during the recent global crisis on expanding its coverage of safety nets, should continue its efforts to harmonize and consolidate the gains and to establish and develop more the capacity of the safety nets to protect poor families in times of crisis. The increasing current agricultural subsidies aimed at increasing the productivity growth of the sector and exports of agricultural products but are likely to be an inefficient way to protect poor families from the effects of food price increases.

Montenegro, which during the last crisis has increased its budget, oriented towards social assistance, has a fairly rigid threshold for eligibility in the program of last resort, should address the lack of flexibility in the program (and the payment of children that are associated with the main program) in times of crisis.

Serbia was pro-active ding the recent shocks of food by seeking moderation of food prices by banning exports, but these seem to have found little susses, while its social assistance as a last resort continued its long-term trend of expansion coverage. To make the most effective responses to a food shock, efforts to increase the flexibility of the social assistance system seems to seek to improve both the coverage of the poor and the size of benefits, in accordance with recent reforms.

Albania should continue its recent reforms to tighten the eligibility criteria for social assistance as a last resort, information systems management and supervision. Regular monitoring of social impacts is undermined by the lack of annual data on poverty and its distribution.

Poverty in Albania has multidimensional character. It is not only identified with unemployed or with families living in economic poverty, but it also represents categories which are excluded from the fundamental right to have a flat, adequate food, heating and clothing in winter, work in accordance with physical skills and education level, school close to home, access to health services, protection from predation and violence, right and voice to demand the rights

Kosovo, which has a well-targeted program but with limited coverage of the poor, should continue investing in increasing not only the amount for large families with children but also in expanding the coverage of the program.

Although Kosovo had smaller consequences from the recent financial crisis compared to most other countries in Europe, it continues to be one of the poorest countries in Europe.

HBS survey of 2009 shows similar rates of poverty in urban and rural areas, although this conclusion is sensitive to the choice of poverty line.

Kosovo's population is extremely young, and young children are disproportionately poor.

Education and employment are closely related to poverty status. In general, the high level of unemployment in Kosovo is another important influence on high levels of poverty.

Poverty remains a concern for Kosovo politics as poverty rate is among the highest in Europe. Identifiable groups of the population are excluded from society about "different types of deprivation and barriers, which alone or together, inhibit full participation in areas such as employment, education, health, housing, culture, access to the right the benefit of family support as well as training and employment opportunities".

Undoubtedly, the poverty in Kosovo society is an issue that is present every person living in Kosovo, especially at those who are without work, without income or are uninsured. In this context, I believe that the problem of poor people and the ratio between them and the rich is not just an economic issues or a technical problem that can be solved immediately or that it can be handled only by written just different plans of action in order the fight poverty.

The Republic of Kosovo is far from meeting the Millennium Development goals, which aimed at reducing significantly the global poverty, to increase the level of education, gender equality and health by 2015 .

\section{References}

Business Insider, (2013), "The 25 most miserable places in the world", http://www.businessinsider.com/most-miserable-countries-in-theworld-2013-2?op=1 [23.01.2015].

Coudouel, A., Hentchel, J.S. and Wodon, Q.T., (2004), "Poverty measurement and analysis", Washington, D.C.: The World Bank.

Kosova Press, (2009), "Rritet numri i te varferve ne Rumani", http://www.kosovapress.com/sq/arkiva/rritet-numri-i-te-varferve-ne-rumani78330/?old=1 [02.02.2015]. 
Ravallion, M., (1998), "Poverty Lines in Theory and Practice", Washington, D.C.: The World Bank.

The World Bank, (2001), "Bulgaria: Poverty Assessment", Washington, D.C.: The World Bank.

The World Bank, (2003), "Bosnia and Herzegovina: Poverty Assessment”, Washington, D.C.: The World Bank.

The World Bank, (2003), "Romania - Poverty Assessment", Washington, D.C.: The World Bank

The World Bank, (2005), "Macedonia, former Yugoslav Republic of - Poverty Assessment for 2002-2003", Washington, D.C.: The World Bank.

The World Bank, (2007), "Croatia - Living Standard Assessment: Volume I \& II", Washington, D.C.: The World Bank.

The World Bank, (2007), "Romania - Poverty Assessment, Analytical and Advisory Assistance Program", Washington, D.C.: The World Bank.

The World Bank and Kosovo Statistical Agency, (2011), "Poverty on consumption in the Republic of Kosovo for 2009", Prishtina: Office of World Bank in Kosovo.

The World Bank and Kosovo Statistical Agency, (2012), "Report on Economic Development", Prishtina The World Bank, (2012), "Evropa Juglindore: Raporti i Zhvillimeve Ekonomike Nr.3 - Nga recesioni i dyfishtë në reforma të përshpejtuara”.

The World Bank and INSTAT, (2013), "Albania: The Trend of Poverty 2002-2005-2008-2012"

The World Bank and Kosovo Statistical Agency, (2013), "Poverty on consumption in the Republic of Kosovo for 2011, Prishtina: Office of World Bank in Kosovo. 
